\title{
The Correlation of Lifestyle and Features on Motivation to Purchase Sharia Compliant Hotel in Jakarta
}

\author{
Candra Hidayat \\ Post graduate student \\ Sekolah Tinggi Pariwisata Trisakti \\ Jakarta, Indonesia \\ candrahidayat189@gmail.com
}

\begin{abstract}
Muslim growth around the world is perhaps the most striking and Sharia is more popular and becoming the lifestyle of Muslim people today. Developed tourism for Muslim tourists services in hotels, restaurants and travel tours are really potential. The study was conducted to provide the author a better understanding on how to establish a Sharia Compliant Hotel in Indonesian in relations the influence lifestyle of customer and features of the hotel are related to the motivation to purchase of Sharia Compliant Hotel. In this study focused at Jakarta province and consists of 5 hotel category: 5 Star Hotel, 4 Star Hotel, 3 Star Hotel, Budget Hotel and Hostel. Type of study is descriptive correlational and the research focuses use primary data, it will be taken with Questionnaire surveys for data collection. The 500 questionnaire had been spread to the respondents, and 369 questionnaires had been collected. There is correlation of lifestyle of customer and features Sharia Compliant Hotel on operation, development and financial on motivation to purchase Sharia Compliant Hotel which indicates positive correlation significant at the 0.001 level. Increasing Muslim concern for products and services that complement their faith becomes new trend and development which gradually pinpoint the emergence of the role of Islam in the region, especially in tourism and hospitality industry. Therefore, the investment and adoption of business practices and financialbased planning according to the principles of Islam and Sharia will be a potential tourism and hospitality business.
\end{abstract}

Keywords- Muslim Tourism, Sharia Compliant Hotels, Descriptive Correlational, Jakarta - Indonesia

\section{INTRODUCTION}

\section{A. Population}

The expected growth of Islam around the world is perhaps the most striking finding in the recent Pew Research Center report projecting the future of religious groups. Indeed, Muslims will grow more than twice as fast as the overall world population between 2010 and 2050 and, in the second half of this century, will likely surpass Christians as the world's largest religious group. While the world's population is projected to grow $35 \%$ in the coming decades, the number of Muslims is expected to increase by $73 \%$-from 1.6 billion in 2010 to 2.8 billion in 2050. In 2010, Muslims made up $23.2 \%$ of the global population. Four decades later, they are expected to make up about three-in-ten of the world's people (PEW Research, 2015).

Spread across a chain of thousands of islands between Asia and Australia, Indonesia has the world's largest Muslim population and Southeast Asia's biggest economy (www.bbc.com, 2015). Furthermore Indonesia is the largest country archipelago and has the second longest coastline in the world. The land and the sea of Indonesia are a rich and diverse natural environment, and this gives it strong potential for tourism development (United Nation, 2001, p. 43).

According to the Regulation of Republic Indonesia No. 29 2007 is the nation's capital city of Indonesia is Jakarta. Based on Governor's decision No. 1227 of 1989, an area of Jakarta is $7659.02 \mathrm{~km} 2$, consisting of land covering an area of 661.52 $\mathrm{km} 2$, including 110 islands in the Thousand Islands, and a sea area of $6997.50 \mathrm{~km} 2$.Jakarta consists of five kota or kotamadya (cities/municipalities), each headed by a mayor - and a kabupaten (regency) headed by a bupati (regent). The cities/municipalities of Jakarta are: Central Jakarta, East Jakarta, North Jakarta, South Jakarta, West Jakarta and the only regency (kabupaten) of Jakarta is: Thousand Islands (Jakarta, 2008). Moreover religion in Jakarta, according to data from Indonesian Statistic in 2010, the composition of religious adherents in the city are Islam (85.36\%), Christian $(7.54 \%)$, Catholics (3.16\%), Hindus (0.21\%), Buddha (3.30\%) and Konghucu (0,06\%), Others (0,03\%) (BPS, 2011).

\section{B. The number of tourist arrivals}

The number of tourist arrivals to Jakarta through three entrances (Soekarno-Hatta Airport, Tanjung Priok harbour, and Halim Perdana Kusuma airport) in August 2015 to reach 258.916 visitors, an increase of 43.98 percent compared to a visitor by foreign tourists in July 2015 , amounting to 179.825 visitors. Likewise, if compared with foreign tourists visit the same month the previous year, the number of a visitor by foreign tourists in August 2015 increased by 15.33 percent. Ten nationalities became the most visitors to the city of Jakarta 
for the month of August 2015 are China (34.009 visitor); Malaysia (24.463 visitor); Japan (22.872 visitor); Saudi Arabia (21.626 visitor); Singapore (18.120 visitor); South Korea (11.217 visitor); USA (9467 visitor); Netherlands (7.848 visitor); Germany (7597 visitor) and India (7375 visitor). Hotel room occupancy in August 2015 reached 57.67 percent, an increase of 0.49 points from the Hotel room occupancy in July 2015, which reached 57.18 percent. Likewise, if compared to the Hotel room occupancy in August 2014, which reached 56.75 percent, the Hotel room occupancy in August 2015 of 0.92 point's higher (Transportation, 2015).

\section{Laws}

In the study of Islam, Sharia is an Arabic word which means the "path that should be followed by Muslims" (Doi, 1984). And Sources of Sharia, There are two main sources of the Sharia: Al-Quran and the Sunnah of Prophet Muhammad (peace be upon him).

Sharia or Halal tourism tourist according to the Regulation of the Minister of Tourism and Creative Economy Indonesia N0. 22014 is a concept that integrates the values of Sharia into tourism activity by providing facilities and services in accordance with the provisions of Sharia, is one of the latest tourism trends.

\section{Economy}

Based on research information from the global Islamic economy 2013 firstly Muslim traveler spending is expected increasing from $\$ 137$ billion in 2012 (excluding Hajj and Ummrah) to $\$ 181$ billion in 2018 (Table 1). This around $12.5 \%$ from global tourist expenditure. Indonesia is number fifth for Muslim tourism expenditure including accommodation, food and drinks, transport, and other activities which is around 7.2 billion US dollar. And Soekarno-Hatta international airport in Jakarta is number fifth the fastest growing airport in the world, around $10.3 \%$ growth in comparison around the world.

TABLE I. SUMMARY OF VARIOUS RESEARCH INFORMATION FROM THE GLOBAL ISLAMIC ECONOMY REPORT 2013

\section{Research Information}

Global Muslim spending on travel (outbound) to be $\$ 137$ billion in 2012 (excluding Hajj and Ummrah). This expenditure is expected to grow to $\$ 181$ billion market by 2018 . This market is $12.5 \%$ of global expenditure.

Top Muslim tourism expenditure source countries (US\$ Billion, in 2012):

1. Iran $\$ 18.2$

2. Saudi Arabia \$ 17.1

3. UAE $\$ 10.1$

4. Kuwait $\$ 7.4$

5. Indonesia $\$ 7.2$

Fastest growing airports in the world in 2013

1. Istanbul (Turkey) $20.2 \%$

2. Dubai (UAE) $14.7 \%$

3. Kuala Lumpur (Malaysia) $10.3 \%$

4. Incheon (South Korea) $10.3 \%$

5. Jakarta (Indonesia) $10.3 \%$
Indonesia itself has an Islamic tourism potential is enormous, including : 1. Endowment factors such as the number of Indonesia's Muslim population of about $88.2 \%$ of the total Indonesian population and $12.9 \%$ of the total Muslim world; 2. Internalization elements of Sharia tour in social and cultural life of society as an everyday lifestyle trends such as hijab and fashion trends among the Indonesian Muslim women including young people; 3 . Increased awareness of Indonesian Muslims as the choice of food, cosmetics, as well as drugs that do not contain alcohol kosher for example; 4. The fact that most of the elements and characteristics of Sharia tour actually runs automatically in the sphere of social life and the world of work, such as the option to use Islamic banking where the mosque or the mosque at tourist sites, shopping malls, hotels, restaurants, and others; Qibla pointer in hotels; the lunch and coffee break in the morning and evening at various seminars allow Muslims to pray mandatory or sunnah.

Director General of Marketing Tourism, Esthy Reko Astuti said that evolving and promoting business services in hotels, restaurants and travel tours in tourism are really potential. This will achieve the ability of developed tourism for Muslim tourists in the Middle East. It specifically focuses on countries which the majority citizens are Muslim in the Middle East because their economy is growth up rapidly in the middle of economic recession of Europe and United State (MUI, 2013).

LSU Tourism announced that the implementation of Shariah in a hotel business is profitable, moreover, the segmented Shariah is more popular and becoming the lifestyle of Muslim people today. The Chairman of Shariah Hotel and Restaurant Association, Riyanto Sofyan tells to Mi'raj Islamic News Agency (MINA) that the number of sales increases and the average level of occupancy reach seventy until eighty percent (LSU Tourism, 2014).

\section{LITERATURE REVIEW}

\section{A. Islamic Tourism}

Islamic Tourism focuses on such issues such as engagement (by Muslims), places (Islamic destinations), products (residential places, foods, and beverage), dimensions (economic, cultural, religious, etc.), and managing service processes (marketing and ethical issues). Motivations and intentions are remarkably important in Islam since they are related to attitudes and their outcomes (Ala-Hamarneh, 2011; Hassan, 2007; 2004; Henderson, 2010 cited in Mohamed 2013).

\section{B. Consumer Behaviour}

Schifman and Kanuk (2010, p. 07) "Consumer behavior is the term consumer behavior that consumer display in searching for, purchasing, using, evaluating, and disposing of product and services that they expect will satisfy their needs". Furthermore according to Kotler and Armstrong (2012, p. 133), consumer buyer behavior refers to the buying behavior of final consumers individuals and households that buy goods and services for personal consumption. 


\section{Lifestyle}

Based on the belief that Islam is a comprehensive way of life with solutions for all predicaments, the term Islamization consists of a wide variety of approaches that seek to implement Islamic values into any given scenario seen as problematic by a religious perspective. Islamization has led to increasing awareness among Muslims resulting in the need for Islamic options for their needs as opposed to the majority of options currently available. (Muhammad, 1989, p. 24 in Battour 2010).

According to Assael (1995, p. 373) lifestyle is defined as "a mode of living that is identified by how people spend reviews their time (activities), what they consider important in their environment (interest), and what they think of themselves and the world around them (opinions). Moreover Bei (2000) pointed out that two methods for applying lifestyle to market segmentation exist-general lifestyle research and specific lifestyle research. General lifestyle research focuses on the personal activities, interests and opinions of consumers in their daily lives, whereas specific lifestyle research emphasizes the responses of consumers pertaining to a particular product.

\section{Features}

Features according to Kotler and Armstrong (2008, p. 273) is defined as a means of features are a competitive tool for differentiating the company's products from competitor's product.

\section{E. Sharia Compliant Hotel}

Sharia Compliant Hotel which is different from normal Hotel. The differences involve most of overall hotel features which is include room concept, facilities offered, food and beverage, Kitchen, Housekeeping and workers dress code. This different concept create tourist attention to gain new experience in their vacation. Sharia Compliant Hotel can be defined as a hotel that provides services in accordance to the Sharia principles (Shamim Yusuf, 2009).

Rosenberg and Choufany (2009), divided the Sharia Compliant Hotel into three divisions specifically on operations, design \& interior and financial. Operation (No alcohol, Halal food only, The staff are mainly Muslim, Segregation of male and female staff at segregated floors, Conservative TV service and Quran \& prayer mats available in each room). Development Design \& Interior (Separate function halls for males and females, Markers in the room indicating the direction of Mecca, No entertainment venues such as night club, Position of beds and toilets should not face the direction of Mecca, Art in the hotel should not the depict the human form, Separate wellness facilities for males and females and Separate floors for single male, single females and families). Financial (Hotel financed through Islamic financial arrangement and Hotel should follow the zakat principles (giving back the community).

\section{F. Motivation}

Push-pull theory has been widely used in previous studies to explain motivation (e.g. Baloglu \& Uysal, 1996; Cha et al., 1995).Tourists are pushed by their biogenic and emotional needs to travel and pulled by destination attributes (Yoon \& Uysal, 2005 cited in Cohen et al., 2013).

\section{G. Purchase Decision}

Kotler and Armstrong (2008, p. 129) defines the purchase decision as a process in which consumers recognize the problem, seeking information about a particular product or brand and evaluate how well each alternative can solve the problem which then leads to a purchase decision.

\section{MethodOLOGY}

\section{A. Research Method}

The study was conducted to provide the author a better understanding on how to establish a Sharia Compliant Hotel at Jakarta in relations the influence lifestyle of customer and features of the hotel are related to the motivation to purchase of Sharia Compliant Hotel. The questionnaires were distributed during period $1^{\text {st }}$ May 2016 until $15^{\text {th }}$ June 2016 or 1 and half month research. From both within Jakarta (domestic travelers) and also the foreigners (international travelers which include foreigners residing/working at Jakarta) in order to get a balance and reliable understanding and representations of the current demand towards the Sharia Compliant Hotel. Based on the aims of this study so that the type of study is correlational study, Kumar (2011) said that the main emphasis in a correlational study is to discover or establish the existence of a relationship/ association/ interdependence between two or more aspects of situations.

\section{B. Conceptual Framework}

This study intends to explore the influences of lifestyle and features on their purchase decision-making.

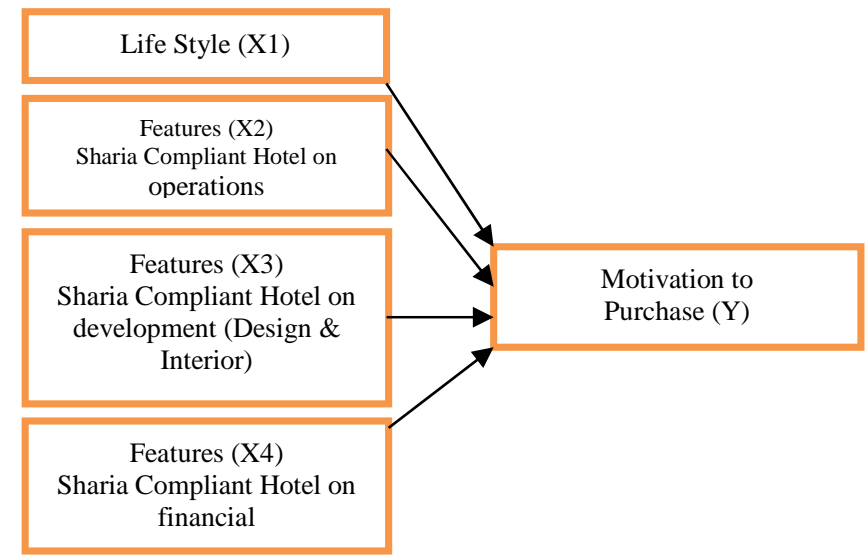

Fig. 1. Conceptual Framework

Based on Kotler and Armstrong (2008, p. 129), the purchase decision as a process in which consumers recognize the problem, seeking information about a particular product or 
brand and evaluate how well each alternative can solve the problem which then leads to a purchase decision. Variable and Indicator showed in Table 2.

Duman (2011) proposed to define Islamic Tourism as, "All tourism activities by Muslims that originate from Islamic motivations and are realized according to Sharia principles."

\section{TABLE II. CONCEPTUAL FRAMEWORK}

\begin{tabular}{cl}
\hline \multicolumn{1}{c}{ Variable } & \multicolumn{2}{c}{ Indicator } \\
\hline & $\begin{array}{l}\text { Gender, Marital status, Nationality and } \\
\text { Religion }\end{array}$
\end{tabular}

Lifestyle

Lifestyle to market segmentation exist

$\begin{array}{ll} & \begin{array}{l}\text { No alcohol } \\ \text { Halal food only } \\ \text { The staff are mainly Muslim } \\ \text { Features }\end{array} \begin{array}{l}\text { Segregation of male and female staff at } \\ \text { Sharia Compliant } \\ \text { Segregated floors } \\ \text { Conservative TV service } \\ \text { Quran \& prayer mats available in each } \\ \text { room }\end{array} \\ & \begin{array}{l}\text { Separate function halls for males and } \\ \text { females } \\ \text { Markers in the room indicating the } \\ \text { direction of Mecca }\end{array} \\ \text { No entertainment venues such as night } \\ \text { club } \\ \text { Position of beds and toilets should not face } \\ \text { the direction of Mecca } \\ \text { Art in the hotel should not the depict the } \\ \text { human form } \\ \begin{array}{l}\text { Hotel Development } \\ \text { (Design \& Interior) }\end{array} \\ \begin{array}{l}\text { Separate wellness facilities for males and } \\ \text { females } \\ \text { Separate floors for single male, single } \\ \text { females and families }\end{array}\end{array}$

Table II. Cont.

\begin{tabular}{ll}
\hline $\begin{array}{l}\text { Features } \\
\text { Sharia Compliant } \\
\text { Hotel Financial }\end{array}$ & $\begin{array}{l}\text { Hotel financed through Islamic financial } \\
\text { arrangement } \\
\text { Hotel should follow the zakat principles } \\
\text { (giving back the community) }\end{array}$ \\
$\begin{array}{l}\text { Motivation } \\
\text { Purchase }\end{array}$ & $\begin{array}{l}\text { Push \& Pull Motivation } \\
\text { pushed by their biogenic and } \\
\text { emotional needs to travel and } \\
\text { pulled by destination attributes }\end{array}$ \\
\hline
\end{tabular}

\section{Hypothesis}

Based on the study of theoretical and empirical amended previously, then the hypothesis proposed in this study are as follows:

H1: There is the influence of lifestyle on motivation to purchase Sharia Compliant Hotel;

$\mathrm{H} 2$ : There is the influence of features Sharia Compliant Hotel on operations on motivation to purchase Sharia

Compliant Hotel;

H3: There is the influence of features Sharia Compliant Hotel on development (design and interior) on motivation to

Purchase Sharia Compliant Hotel;

H4: There is the influence of features Sharia Compliant Hotel on financial on motivation to purchase Sharia

Compliant Hotel;

TABLE III. THE VARIABLES AND MEASUREMENTS

\begin{tabular}{|c|c|c|c|}
\hline Variable & Indicator & $\begin{array}{c}\text { Scale of } \\
\text { Measurement }\end{array}$ & Source \\
\hline Demo-graphic & $\begin{array}{l}\text { Gender } \\
\text { 1. Male } \\
\text { 2. Female } \\
\text { Marital Status } \\
\text { 1. Single } \\
\text { 2. Married } \\
\text { Nationality } \\
\text { 1. Indonesian } \\
\text { 2. Non-Indonesian } \\
\text { Religion } \\
\text { 1. Islam } \\
\text { 2. Christian } \\
\text { 3. Buddhist } \\
\text { 4. Hindu } \\
\text { 5. Others }\end{array}$ & Nominal & \\
\hline Lifestyle (X1) & $\begin{array}{l}\text { Lifestyle to market segmentation exist: } \\
\text { (Likert Scale, 1-5) }\end{array}$ & Interval & Bei (2000) \\
\hline
\end{tabular}


Table III. Cont.

\begin{tabular}{|c|c|c|c|}
\hline $\begin{array}{l}\text { Features (X2) } \\
\text { Sharia Compliant Hotel } \\
\text { Operation }\end{array}$ & $\begin{array}{l}\text { Sharia Compliant Hotel Operations: } \\
\text { (Likert Scale,1-5) } \\
\text { 1. No alcohol } \\
\text { 2. Halal food only } \\
\text { 3. The staff are mainly Muslim } \\
\text { 4. Segregation of male \& female staff at } \\
\text { segregated floor } \\
\text { 5. Conservative television service } \\
\text { 6. Quran and prayer mats available in each room }\end{array}$ & Interval & $\begin{array}{l}\text { Rosenberg and } \\
\text { Choufany (2009) }\end{array}$ \\
\hline \multirow[t]{2}{*}{$\begin{array}{l}\text { Features (X3) } \\
\text { Sharia Compliant Hotel } \\
\text { Development } \\
\text { (Design and Interior) }\end{array}$} & $\begin{array}{l}\text { Sharia Compliant Hotel Development: } \\
\text { (Likert Scale,1-5) } \\
\text { 1. Separate function halls for males and females } \\
\text { 2. Markers in the room indicating the direction of } \\
\text { Mecca } \\
\text { 3. No entertainment venues such as night club }\end{array}$ & Interval & \\
\hline & $\begin{array}{l}\text { 4. Position of beds and toilets should not face the } \\
\text { direction of Mecca } \\
\text { 5. Art in the hotel should not the depict the } \\
\text { human form } \\
\text { 6. Separate wellness facilities for male \& female } \\
\text { 7. Separate floors for single male, single female } \\
\text { \& Family }\end{array}$ & & \\
\hline $\begin{array}{l}\text { Features }(\mathrm{X} 4) \\
\text { Sharia Compliant Hotel } \\
\text { Financial }\end{array}$ & $\begin{array}{l}\text { Sharia Compliant Hotel Financial: } \\
\text { (Likert Scale,1-5) } \\
\text { 1. Hotel financed through Islamic financial } \\
\text { arrangement } \\
\text { 2. Hotel should follow the zakat principles } \\
\text { (giving back the community) }\end{array}$ & Interval & \\
\hline $\begin{array}{l}\text { Motivation to Purchase } \\
\text { (Y) }\end{array}$ & $\begin{array}{l}\text { Push and Pull Motivation: } \\
\text { (Likert Scale,1-5) } \\
\text { pushed by their biogenic and emotional needs to } \\
\text { travel and pulled by destination attributes }\end{array}$ & Interval & $\begin{array}{l}\text { Cohen } \\
(2013)\end{array}$ \\
\hline
\end{tabular}

\section{The Variable and Measurement}

This study is trying to examine the relationship between demand represented by the lifestyle of customer and features of the hotel as Independent variable (Variable X) based on the theory Bei (2000) pointed out that two methods for applying lifestyle to market segmentation exist-general lifestyle research and specific lifestyle research. General lifestyle research focuses on the personal activities, interests and opinions of consumers in their daily lives, whereas specific lifestyle research emphasizes the responses of consumers pertaining to a particular product and the theory of Rosenberg and Choufany (2009), divided the Sharia Compliant Hotel into three divisions specifically on operations, design \& interior and financial. Kotler and Armstrong (2008, p. 129) defines the purchase decision as a process in which consumers recognize the problem, seeking information about a particular product or brand and evaluate how well each alternative can solve the problem which then leads to a purchase decision. And the motivation as Dependent (Variable Y) based on the theory Cohen push and pull motivation explains pushed by their biogenic and emotional needs to travel and pulled by destination attributes.

Between independent and dependent in this research has demographic differences of the respondents as moderating variable. The scheme of the variables, dimensions, indicators and the scale of measurement can be seen in the table 3 .

\section{E. Sampling Design}

According to Roscoe (1975), the size of a sample is between 30 to 500 samples and 500 questionnaires will be distributed to respondent. The questionnaires will be collected every day (week-day and week-end) starting May $1^{\text {st }}$ until June

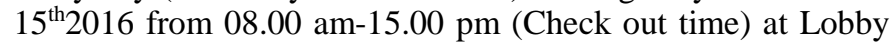
hotel. Based on the location in city, that make researcher can collect data every day. The questionnaires will be distributed toward 100 questionnaires for each hotel and estimating time twenty five minutes for every questionnaires.

\section{F. Data Collection Procedure}

The research focuses use primary data. Primary data are the new data or original data generated by the research, whereas secondary data are existing data or information collected for a purpose other than that of the researcher (Finn et al., 2000). In this research focused at Jakarta province and consists of 5 hotel category: 5 Star Hotel, 4 Star Hotel, 3 Star Hotel, Budget Hoteland Hostel.

This research to know the mean score of the guest, the maximum and minimum value and standard deviation in order to know the condition of the respondent's answer " 5 " is high and " 1 " is low. The variable consists of 45 items (as mention before). Question number 1 until number 6 is the questions for demographic, question number 7 until number 21 is the questions for lifestyle, Question number 22 until 35 is the 
question for features of Sharia Compliant Hotel Operation, question 36 until 45 is the questions for purchase motivation of customer.

In analyzing the data for this study, the statistical software, SPSS version 20.0, was used as the instrument for the data analysis. To address these need two kinds of testing i.e. the reliability test and validity test. A good questionnaire must have at least validity and reliability." (Cronbach \& Meehl, 1955, pp. 281-302 cited in Yadhisaputra, 2013, p. 95).

\section{1) Validity Test}

The questionnaire had been sent to the three experts to check whether the questionnaire items could measure what they were designed for. Those Experts were academically qualified in Education and Culture of Embassy of the Republic of Indonesia, in Bangkok (Dr. Yunardi Yusuf), Burapha University (Assistant Prof. Dr. Sombat Thamrongsinthaworn) and Graduate School Trisakti Institute of Tourism (Djoko Sudibyo SE., MM., Ph.D).

Those Experts read the relevance of each item to the purpose of the questionnaire and appropriateness of the content areas, and then checked the evaluation form by using Itemobjective Congruence Index (IOC) as the validation method for the relevancy of the content and the objective of the questionnaire. The evaluation form used a 3 point scales $(1=$ Relevant, $0=$ Uncertain, $-1=$ Uncertain). According to Booncherd (1974), the acceptable value should be higher or equal to 0.5 ( $\geq 0.5)$ the result of current questionnaire was 0.88 and it means higher. Based on the result of the items analysis all of the items were acceptable and relevant. Then the items were improved according to the three experts' opinion and suggestion.

This study combines two methods of validation by using IOC method and Correlational validation method. After doing pre-testing of the items to 100 respondents, previously the items in the questionnaire were contained of 45 items (35 items of independent variable and 10 items of dependent variable). The result of validity test shows that there are all the items which were valid.

\section{2) Reliability Test}

For pre-testing the consistency of this research, the questionnaire had been spread to 100 respondents. And here is the result of reliability test. Reliability test result of Lifestyle and Features (X Variable). The Cronbach's Alpha for X Variable is 0.958 for 29 items in Independent Variable. It means that the 29 items are considered as good and reliable to be used. Moreover Reliability test result of Motivation (Y Variable). The result for Dependent variable of this research shows that the Cronbach's Alpha is 0.945 for 10 items. The items are considered as good and reliable as well.

\section{3) PCA (Principal Component Analysis)}

The third objective is to measure by PCA (Principal component analysis).According to Jolliffe (2002) the aim of the method is to reduce the dimensionality of multi-variate data whilst preserving as much of the relevant information as possible. It is a form of unsupervised learning in that it relies entirely on the input data itself without reference to the corresponding target data (the criterion to be maximized is the variance).

\section{4) Pearson Correlation}

Based on the research objectives, the results were obtained by using the Pearson Correlation (r) to identify the significant relationship between lifestyle and features on motivation to purchase Sharia Compliant Hotel in Jakarta. Triola (2008) stated that the Pearson Correlation (r) of correlation is a measurement tool for the linear relationship between two or more variables. Usually, it describes the strength and direction of the linear relation among 2 variables (Pallant, 2011).The value of Pearson $\mathrm{R}$ constantly lies between- 1 and +1 , where- 1 shows a perfect negative relationship, +1 is a perfect positive relationship and 0 means the perfect absence of relationship and it is also referred as the bivariate correlation of the zeroorder correlation coefficient (Vaus, 2002). The rule of thumb for interpreting the relationship in a correlation is based on Guildford (1973).

\section{RESULTS}

Unfortunately five star hotel is under renovation, therefore the researcher only research at 4 hotel category. The research was conducted by using primary data which is using 45 items in the questionnaire. The 500 questionnaire had been spread to the respondents, and 369 questionnaires had been collected.

\section{A. Profile of Respondent}

The majority gender is male with 231 persons from a total of 369 respondents or $62.6 \%$ from all respondents. While the female gender is 138 persons from 369 respondents or $37.4 \%$ of all respondents and the single respondent is 172 persons from a total of 369 respondents or $46.6 \%$ from all respondents. While the married respondent is 197 persons from 369 respondents or $53.4 \%$ of all respondents. The mostly respondents are local guest from Indonesia around $99.2 \%$ and the most religion is Islam. However, another religions purchased Sharia Compliant Hotel as their option. The most guest around $70 \%$ know about Sharia Compliant Hotel rather than the guest who does not know about Sharia Compliant Hotel. Finally the total respondent is have experienced staying in Sharia Compliant Hotel.

\section{B. Finding for The Research Objectives}

1) Level influence of lifestyle on motivation to purchase Sharia Compliant Hotel

The overall result for level influence of lifestyle on motivation to purchase Sharia Compliant Hotel minimum statistic 2.67 and maximum statistic 5.00. The mean statistic 4.1149 and standard deviation 0.56822 .

2) Level influence of features Sharia Compliant Hotel on operations on motivation to purchase Sharia Compliant Hotel

The overall result for level influence of Features Sharia Compliant Hotel on operation on motivation to purchase Sharia Compliant Hotel minimum statistic 2.33 and maximum statistic 5.00. The mean statistic 4.2475 and standard deviation 0.61631 . 
3) Level influence of features Sharia Compliant Hotel on development on motivationto purchase Sharia Compliant Hotel

The overall result for level influence of Features Sharia Compliant Hotel on development (design and interior) on motivation to purchase Sharia Compliant Hotel minimum statistic 2.14 and maximum statistic 5.00. The mean statistic 4.0902 and standard deviation 0.62740 .

4) Level influence of features Sharia Compliant Hotel on financial on motivationto purchase Sharia Compliant Hotel

The overall result for level influence of Features Sharia Compliant Hotel on financial on motivation to purchase Sharia Compliant Hotel minimum statistic 2.00 and maximum statistic 5.00. The mean statistic 4.1328 and standard deviation 0.78452 .

\section{5) Level motivation to purchase Sharia Compliant Hotel}

The overall result for motivation to purchase Sharia Compliant Hotel minimum statistic 2.60 and maximum statistic 5.00. The mean statistic 4.0477 and standard deviation 0.61308 .

\section{6) Multicollinearities test}

Klein (1962) explain that VIF is bigger than $1 /\left(1-\mathrm{R}^{2}\right)$ or tolerance is less than $\left(1-R^{2}\right)$ is significant multicollinearity. The table below show the result from multicollinearity test and $\mathrm{R}=$ 0.855 , and it showed in Table 4.

\section{TABLE IV. MULTICOLLINEARITIES TEST}

\begin{tabular}{ll}
\hline Lifestyle & Lifestyle \\
VIF $>1 /\left(1-R^{2}\right)$ & Tolerance $<\left(1-\mathrm{R}^{2}\right)$ \\
$2.279<1 /(1-0.731)$ & $0.439>1-0.731$ \\
$2.279<1 / 0.269$ & $0.439>0.2689$ \\
$2.279<3.71747$ & \\
Features on operation & Features on operation \\
VIF $>1 /(1-\mathrm{R} 2)$ & Tolerance $<(1-\mathrm{R} 2)$ \\
$2.889<1 /(1-0.731)$ & $0.346>1-0.731$ \\
$2.889<1 / 0.269$ & $0.346>0.2689$ \\
$2.889<3.71747$ & \\
Features on design & Features on design \\
VIF $>1 /(1-\mathrm{R} 2)$ & Tolerance $<(1-\mathrm{R} 2)$ \\
$3.187<1 /(1-0.731)$ & $0.314>1-0.731$ \\
$3.187<1 / 0.269$ & $0.314>0.2689$ \\
$3.187<3.71747$ & \\
Features on operation & Features on operation \\
VIF $>1 /(1-\mathrm{R} 2)$ & Tolerance $<(1-\mathrm{R} 2)$ \\
$1.858<1 /(1-0.731)$ & $0.538>1-0.731$ \\
$1.858<1 / 0.269$ & $0.538>0.2689$ \\
$1.858<3.71747$ & \\
\hline
\end{tabular}

\section{Analysis Results}

1) There is the influence of lifestyle on motivation to purchase Sharia Compliant hotelinJakarta.

Hypothesis of the research

$\mathrm{HO}$ : there is no the influence of lifestyle on motivation to purchase Sharia Compliant Hotel

$\mathrm{H1}$ : there is the influence of lifestyle on motivation to purchase Sharia Compliant Hotel
TABLE V CORRELATION OF LIFESTYLE ON MOTIVATION TO PURCHASE SHARIA COMPLIANT HOTEL IN JAKARTA

\begin{tabular}{llll}
\hline & & Lifestyle & Motivation \\
\hline \multirow{3}{*}{ Lifestyle } & Pearson Correlation & 1 & $.818^{* *}$ \\
& Sig. (2-tailed) & & .000 \\
& N & 369 & 369 \\
Motivation & Pearson Correlation & $.818^{* *}$ & 1 \\
& Sig. (2-tailed) & .000 & \\
& $\mathrm{~N}$ & 369 & 369 \\
\hline
\end{tabular}

Based on the table 5 above, the correlation between lifestyle on motivation to purchase Sharia Compliant Hotel. It is $\mathrm{r}=0.818, \mathrm{p}=0.000, \mathrm{n}=369$ which indicates strong and positive correlation significant at the 0.001 level.

1. These strength correlation that lifestyle of customer can influence on motivation to purchase Sharia Compliant Hotel is 0.818 of 1 .

2. Sig. (2-tailed) $0,000<0,05 \mathrm{HO}$ is rejected, there is the influence of lifestyle on motivation to purchase Sharia Compliant Hotel.

3. Pearson correlation $r=0,818$ which mean $0.70<r<$ $0.90=$ strong correlation, there is strong correlation of lifestyle on motivation to purchase Sharia Compliant Hotel

2) There is the influenceof features Sharia Compliant Hotel on operationsonmotivation to purchase Sharia Compliant hotel in Jakarta.

Hypothesis of the research

HO: there is no the influence of features Sharia Compliant Hotel on operations on motivation to purchase Sharia Compliant Hotel.

$\mathrm{H} 2$ : there is the influence of features Sharia Compliant Hotel on operations on motivation to purchase Sharia Compliant Hotel.

TABLE VI. CORRELATION OF FEATURES SHARIA COMPLIANT HOTEL ON OPERATIONS ON MOTIVATION TO PURCHASE SHARIA COMPLIANT HOTEL IN JAKARTA

\begin{tabular}{llll}
\hline & & \multicolumn{1}{c}{$\begin{array}{c}\text { Features on } \\
\text { operation }\end{array}$} & Motivation \\
\hline \multirow{2}{*}{ Features on operation } & Pearson & 1 & $.683^{* *}$ \\
& Correlation & & .000 \\
& Sig. (2-tailed) & & 369 \\
N & 369 & 1 \\
Pearson & $.683^{* *}$ & \\
& Correlation & .000 & 369 \\
\hline
\end{tabular}

Based on the Table 6 , the correlation between features Sharia Compliant Hotel on operations on motivation to purchase Sharia Compliant Hotel. It is $r=0.683, p=0.000, n$ $=369$ which indicates moderate and positive correlation significant at the 0.001 level.

1. These strength correlation that features Sharia Compliant Hotel on operations can influence on motivation to purchase Sharia Compliant Hotel is 0.683 of 1 . 
2. Sig. (2-tailed) $0,000<0,05 \mathrm{HO}$ is rejected, there is the influence of features Sharia Compliant Hotel on operations on motivation to purchase Sharia Compliant Hotel.

3. Pearson correlation $r=0,683$ which mean $0.40<r<$ $0.70=$ moderate correlation, there is moderate correlation of features Sharia Compliant Hotel on operations on motivation to purchase Sharia Compliant Hotel

3) There is the influenceof features Sharia Compliant Hotel on developmenton motivation to purchase Sharia Compliant hotelinJakarta.

Hypothesis of the research

HO: there is no the influence of features Sharia Compliant Hotel on development (design and interior) on motivation to purchase Sharia Compliant Hotel.

H3: there is the influence of features Sharia Compliant Hotel on development (design and interior) on motivation to purchase Sharia Compliant Hotel.

TABLE VII. CORRELATION OF FEATURES SHARIA COMPLIANT HOTEL ON DEVELOPMENT (DESIGN AND INTERIOR) ON MOTIVATION TO PURCHASE SHARIA COMPLIANT HOTEL IN JAKARTA

\begin{tabular}{|c|c|c|c|}
\hline & & $\begin{array}{l}\text { Features on } \\
\text { development }\end{array}$ & Motivation \\
\hline \multirow{3}{*}{$\begin{array}{l}\text { Features } \\
\text { development }\end{array}$} & $\begin{array}{c}\text { Pearson } \\
\text { onCorrelation }\end{array}$ & 1 & $.742^{* *}$ \\
\hline & Sig. (2-tailed) & & .000 \\
\hline & $\mathrm{N}$ & 369 & 369 \\
\hline \multirow{3}{*}{ Motivation } & $\begin{array}{l}\text { Pearson } \\
\text { Correlation }\end{array}$ & $.742^{* *}$ & 1 \\
\hline & Sig. (2-tailed) & .000 & \\
\hline & $\mathrm{N}$ & 369 & 369 \\
\hline
\end{tabular}

Based on the Table 7, the correlation between features Sharia Compliant Hotel on development on motivation to purchase Sharia Compliant Hotel. It is $r=0.742, p=0.000, n=$ 369 which indicates strong and positive correlation significant at the 0.001 level.

1. These strength correlation that features Sharia Compliant Hotel on development can influence on motivation to purchase Sharia Compliant Hotel is 0.742 of 1

2. Sig. (2-tailed) $0,000<0,05 \mathrm{HO}$ is rejected, there is the influence of features Sharia Compliant Hotel on development (design and interior) on motivation to purchase Sharia Compliant Hotel.

3. Pearson correlation $r=0,742$ which mean $0.70<r<$ $0.90=$ strong correlation, there is strong correlation of features Sharia Compliant Hotel on development (design and interior) on motivation to purchase Sharia Compliant Hotel.
4) There is the influenceof features Sharia Compliant Hotel on financialon motivation to purchase Sharia Compliant hotel in Jakarta.

Hypothesis of the research

HO: there is no the influence of features Sharia Compliant Hotel on financial on motivation to purchase Sharia Compliant Hotel.

H4: there is the influence of features Sharia Compliant Hotel on financial on motivation to purchase Sharia Compliant Hotel.

TABLE VIII. CORRELATION OF FEATURES SHARIA COMPLIANT HOTEL ON FINANCIAL ON MOTIVATION TO PURCHASE SHARIA COMPLIANT HOTEL IN JAKARTA

\begin{tabular}{|c|c|c|c|c|c|c|c|}
\hline \multirow{4}{*}{ [1] } & \multirow{3}{*}{$\begin{array}{l}\text { Features on } \\
\text { financial }\end{array}$} & \multirow[b]{2}{*}{ [2] } & \multirow[b]{2}{*}{$\begin{array}{l}\text { Pearson } \\
\text { Correlation }\end{array}$} & \multicolumn{2}{|c|}{$\begin{array}{c}\text { Features } \\
\text { financial }\end{array}$} & \multicolumn{2}{|c|}{ on Motivation } \\
\hline & & & & [3] & 1 & [4] & $.614^{* *}$ \\
\hline & & [5] & Sig. (2-tailed) & [6] & & [7] & .000 \\
\hline & & {$[8]$} & $\mathrm{N}$ & [9] & 369 & [10] & 369 \\
\hline \multirow{3}{*}{ [11] } & \multirow{3}{*}{ Motivation } & [12] & $\begin{array}{l}\text { Pearson } \\
\text { Correlation }\end{array}$ & [13] & $.614^{* *}$ & [14] & 1 \\
\hline & & [15] & Sig. (2-tailed) & [16] & .000 & [17] & \\
\hline & & [18] & $\mathrm{N}$ & [19] & 369 & [20] & 369 \\
\hline
\end{tabular}

Based on the Table 8 , the correlation between features Sharia Compliant Hotel on financial on motivation to purchase Sharia Compliant Hotel. It is $\mathrm{r}=0.614, \mathrm{p}=0.000, \mathrm{n}=369$ which indicates moderate and positive correlation significant at the 0.001 level.

1. These strength correlation that features Sharia Compliant Hotel on financial can influence on motivation to purchase Sharia Compliant Hotel is 0.683 of 1

2. Sig. (2-tailed) $0,000<0,05 \mathrm{HO}$ is rejected, there is the influence of features Sharia Compliant Hotel on financial on motivation to purchase Sharia Compliant Hotel.

3. Pearson correlation $r=0,614$ which mean $0.40<r<$ $0.70=$ moderate correlation, there is moderate correlation of features Sharia Compliant Hotel on financial on motivation to purchase Sharia Compliant Hotel

\section{CONCLUSION AND SUGGESTION}

This research has conduct several tests using SPSS software. This summary is analyzed the data and testing the 4 (four) hypothesis based on theoretical models that have been described in chapter II. The overall results obtained showed that all hypotheses can be proven. That the questionnaires are acceptable and shows the variables are correlated to make a realistic analysis. 
TABLE IX. RESULT SUMMARY

\begin{tabular}{|c|c|c|c|c|c|}
\hline No & Item & $\begin{array}{l}\text { Significant (p- } \\
\text { value) }\end{array}$ & $\begin{array}{c}\text { Pearson } \\
\text { correlation (r) }\end{array}$ & Mean & Result \\
\hline 1 & $\begin{array}{l}\text { There is the influence of lifestyle on motivation to purchase Sharia } \\
\text { Compliant Hotel. }\end{array}$ & 0.000 & 0.818 & 4.1149 & Significant \\
\hline 2 & $\begin{array}{l}\text { There is the influence of features Sharia Compliant Hotel on operations } \\
\text { on motivation to purchase Sharia Compliant Hotel }\end{array}$ & 0.000 & 0.683 & 4.2475 & Significant \\
\hline 3 & $\begin{array}{l}\text { there is the influence of features Sharia Compliant Hotel on development } \\
\text { (design and interior) on motivation to purchase Sharia Compliant Hotel }\end{array}$ & 0.000 & 0.742 & 4.0902 & Significant \\
\hline 4 & $\begin{array}{l}\text { There is the influence of features Sharia Compliant Hotel on financial on } \\
\text { motivation to purchase Sharia Compliant Hotel. }\end{array}$ & 0.000 & 0.614 & 4.1328 & Significant \\
\hline
\end{tabular}

From the Table 9, this is certainly proved that there is influence lifestyle of customer and features of Sharia Compliant Hotel, against the decisions to purchase of Sharia Compliant Hotel. Furthermore Muslim lifestyle is more popular today and Sharia business is high potential. Moreover Sharia Compliant Hotel on operation, on development and on financial is suitable and can be developed. In additions the means are high, positive correlation and significant. It indicates high demand for Sharia Compliant Hotel at Jakarta.

The limitation this study is time, budget and difficulties in getting respondents from the international guest.

\section{A. Managerial Implication}

Firstly, Sharia Compliant Hotel can manage mining staff, room and other facilities to provide their demand. The Sharia Compliant Hotel must promote the hotel to attract the foreign tourist so that the business will be growth and wider for the guests who does not know about Sharia Compliant Hotel. Secondly, the highest means are for general lifestyle, focuses on the personal activities, interests and opinions of consumers in their daily lives. And in other side, the lowest means which is specific lifestyle research emphasizes the responses of consumers pertaining to a particular product. Thirdly, overall almost equal by push motivation and pull motivation, but slightly higher pull motivation. Fourthly, increasing Muslim concern for products and services that complement their faith becomes new trend and development which gradually pinpoint the emergence of the role of Islam in the region, especially in tourism and hospitality industry. Therefore, the investment and adoption of business practices and financial-based planning according to the principles of Islam and Sharia will be a potential tourism and hospitality business.

\section{B. Suggestion for the future research}

The future research should be wider in all aspect, such as adding more international respondents instead of domestic respondents, also adding five star hotel category because in this research, five star hotel category is under renovation.

\section{REFERENCES}

Assael, H. (1995), Consumer behavior and marketing action ( $5^{\text {th }}$ ed.), Ohio: South Western Publishing,

Baloglu, S., \& Uysal, M. (1996), Market segments of push and pull motivations: A canonical correlation approach.
International Journal of Contemporary Hospitality Management, 8(3), 32-38.

BBC. (2015), Muslim population and Southeast Asia's biggest economy. Retrieved from http: //www.bbc.com/news/world-asia-pacific-14921238

Bei, Lien-Ti. (2000). The whitepaper on lifestyle: A report of the 2000 survey on Taiwanese consumption habits, Taipei City: Business Weekly Publications.

Booncherd, P., (1974). Evaluation by references criteria, concepts and methods. Faculty of educational study, Srinakrindravirot University ( $1^{\text {st }}$ ed.) Fundamental education division (pp: 89-299). Bangkok: ISBN: 974275-874-3.

BPS. (2011), $\quad$ Retrieved from https://www.bps.go.id/website/pdf_publikasi

Cohen, S. A., Moital, M., \& Prayag, G. (2013). Consumer behaviour in tourism: concepts, influences and opportunities. Current Issues in Tourism. Routledge, 17(10), 872-909.

Doi, A. R. I. (1984), Shariah the Islamic law. London: Ta-Ha.

Duman, T. (2011), Value of Islamic tourism offering: Perspectives from the Turkish experience, World Islamic tourism forum (WITF, 2011), Kuala Lumpur, Malaysia.

Finn, D. J., \& Wang, C. M. (2002), Taking small classes one step further, Washington DC: Mid Atlantic Regional Educational Laboratory.

Jakarta. (2008),, $\quad$ Retrieved from http://www.jakarta.go.id/v2/news/2008/01/GeografisJakarta

Jolliffe, I. T.( 2002), Principal Component Analysis.

$\left(2^{\text {nd }}\right.$ ed). Springer Series in Statistics. New York: SpringerVerlag New York.

Kotler, P., Armstrong, G. (2008), Principles of marketing. Jakarta: Erland.

Kotler. P, Armstrong, G. (2012), Principles of marketing. Global edition $\left(14^{\text {th }}\right.$ ed $)$, Pearson education.

Kumar, R. (2011), Research methodology a step by step Guide for beginners, California: SAGE.

LSU Tourism. (2014), Retrieved from http://lsupariwisata.com/bisnis-hotel-syariahmenguntungkan/

Mohamed, M. (2013), Promoting Islamic tourism in Brunei: Through customers understanding towards the Syariah Compliant Hotel concepts, Retrieved 
fromhttp://eprints.nottingham.ac.uk/27242/1/HajiMoham ed

Muhammad, M. (1989). Toward Islamization of disciplines. Herndon, VA: The International Institute of Islamic Thought.

MUI.

(2013), Retrieved from http://www.halalmui.org/newMUI/index.php/

Pallant, J. (2011), SPSS survival manual (4 ${ }^{\text {th }}$ ed.), New York: McGraw-Hill,

PEW Research. (2013), Retrieved from http://www.pewresearch.org/fact-tank/2015/04/23/whymuslims-are-the-worlds-fastest-growing-religiousgroup/.

Roscoe, J.T. (1975), Fundamental research statistics for the behavioural sciences, $\left(2^{\text {nd }}\right.$ ed.), New York: Holt Rinehart \& Winston.

Rosenberg, P., \& Choufany, H. M. (2009), Spiritual lodging the Shariah-Compliant Hotel concept. HVS Global Hospitality Services-Dubai, 1-7.
Schiffman, L. G., \& Kanuk, L. L. (2010), Consumer behaviour $\left(10^{\text {th }}\right.$ ed.). New Jersey: Prentice.

Shamim, Y. (2009), The real sense of Shariah hospitality concept. In World Halal Forum. (pp. 1-18). n.p.

BPS. (2015), Retrieved from http: //jakarta.bps.go.id/ transportation

Triola, M. F. (2008), Elementary statistics using the Ti-83/84 Plus calculator ( $2^{\text {nd }}$ ed.), New York: Addison Wesley.

Vaus, D., D., (2002), Survey in social research, Routledge: Taylor and Francis Gropu-London. Retrieved from http://www.unescap.org/ttdw/Publications/.

United Nation (UN). (2001), Managing Sustainable Tourism Development, Retrieved from

http: //www.unescap.org/ttdw/Publications/

Yadhisaputra M. (2013), The relationship between HEXACO personality factors and emotional labor of service provider in hospitality and tourism industry. Master Degree Jakarta, Tourism, STP Trisakti. 